\title{
Long term evaluation of field-released genetically modified rhizobia
}

\author{
Viviana CORICH ${ }^{1}$, Alessio GIACOMINI ${ }^{1}$, Elena VENDRAMIN ${ }^{1}$, Patrizia VIAN ${ }^{1}$, Milena CARLOT ${ }^{1}$, Giuseppe CONCHERI $^{1}$, \\ Elisa POLONE${ }^{1}$, Sergio CASELLA ${ }^{1}$, Marco P. NUTI ${ }^{2}$ and Andrea SQUARTINI ${ }^{1 *}$ \\ ${ }^{1}$ Dipartimento di Biotecnologie Agrarie, Università di Padova, Viale dell’Università 16, 35020 Legnaro, Padova, Italy \\ 2 Dipartimento di Biologia delle Piante Agrarie, Università di Pisa, Via del Borghetto 80, 56124 Pisa, Italy
}

This is the report of the first open field release of genetically modified microorganisms (GMMs) in Italy. It covers ten years of monitoring, and follows in-field GMM dynamics from strain release to disappearance below detection limits, as well as assessment of impact on resident microorganisms. The bacteria released belong to the nitrogen fixing legume endosymbiont Rhizobium leguminosarum bv. viciae, and were engineered with non-agronomically-proficient traits, in order to assess their behavior and fate without GMM-specific positive feedback from the plant. A DNA cassette containing mercury resistance and B-galactosidase genes was introduced in either plasmid-borne or chromosomally integrated versions, in order to test the resulting strain stability. A synthetic promoter was used to drive the lacZ gene, conferring high catabolic activity to the GMM. Two different wild-type Rhizobium backgrounds were tested, comparing a non-indigenous vs. an indigenous, highly competitive strain. The latter had much greater persistence, since it was able to survive and establish at technically detectable levels for over four years after release. Selection factors, such as reiterated presence of the plant host, or lactose substrate supply, enhanced long-term survival to different extents. The lactose treatment showed that even a single trophic supplementation can surpass the benefits of symbiotic interaction for a period of several years. Concerning impact, the GMMs did not alter substantially the other soil community general microbiota. However, there were some significant differences in microbiota as a consequence of the Rhizobium inoculation. This effect was observed with either the WT or GMM, and was more evident in the release of the indigenous Rhizobium. Moreover, as the indigenous GMM had its parental, dominant wild-type in the same soil, it was possible to evaluate to what extent the GMM version could result in parent displacement ("self-impact"), and how much the two rhizobia would additively contribute to nodulation.

Keywords: rhizobia / GMM / impact / risk assessment / environmental release

\section{INTRODUCTION}

This work originated within the framework of the prenormative risk assessment guidelines issued in Europe at the onset of the nineties (Nuti et al., 1994). We have since then devoted our effort to the construction and monitoring of model GMMs whose fate has been investigated in open field trials through a ten-year time span, from the first release to their technical extinction, as defined by the detection limits of available methodologies.

We have recently reviewed the collective knowledge gathered after 24 field releases in the Italian territory (Nuti et al., 2003). The present report is the detailed complete outcome of the earliest of these experiments, started in parallel with our previously published joint trials with genetically modified (GM) Azospirillum brasilense and

* Corresponding author: squart@unipd.it
Pseudomonas fluorescens (Basaglia et al., 2003; Corich et al., 1995; Nuti et al., 1997; Resca et al., 2001).

Rhizobium leguminosarum bv. viciae, the nitrogenfixing root nodule microsymbiont of pea and faba bean legume plants, was chosen as host strain for the recombinant genes. It constitutes an example for which a large body of ecological and genetic knowledge is available. In particular, being a widely applied agricultural inoculant, of interest in the areas of biotechnology and marketing, its behavior in soil in relation to massive release, has long been studied. The bacteria were engineered with the same genes to be used as markers for their subsequent tracking. No traits linked to the promotion of crop productivity were at this stage inserted, in order to analyze the sole issue of biosafety.

The genetic markers were selected to fulfill the requirements of: (1) neutrality with respect to the 
environmental selective conditions, in order to not confer advantages or deficiencies to the GMM under normal situations; (2) selectability at the recovery stage, in order to allow a clean and unambiguous monitoring of the released strains when re-isolated from soil; (3) absence of antibiotic resistance genes, to avoid spread of traits prone to jeopardize human clinical therapy. The chosen genes included mercury resistance (the mer operon from $\mathrm{Tn} 1831)$ and a lac $Z$ gene driven by a synthetic promoter. Such a promoter was designed in order to ensure a high level of lac gene expression. This trait was deemed necessary to differentiate the tagged GMM from background lac+ soil microbiota. It was constructed after aligning sequences of published prokaryotic promoters, and extracting the highest scoring consensus for each base position upstream the transcriptional start site. The resulting construct proved to be very efficient, and its gene expression level was stronger than the lac and tac promoters in Rhizobium and E. coli (Giacomini et al., 1994). The gene cassette including the lac and mer determinants was introduced into Rhizobium leguminosarum either in plasmid-borne form, or integrated into the chromosome. Two alternative regulation modes were devised by either interposing or omitting a lac operator between the synthetic promoter and the reporter gene. Before the field release stage, the resulting GMM strains were tested for over 500 days in microcosms in three different inoculant carrier substrates, assessing their survival, genetic stability and interspecies gene exchange (Corich et al., 1996 and 2000). We found that the stability of these genetic modifications was strongly dependent on the means of insertion into the bacterium genome. Chromosomal integration gave the most stable result, while the absence of operator in a plasmid-borne gene cassette was the one most prone to loss by segregation.

The present paper presents a survey carried out over a ten-year period (1994-2004), starting with the open field release of the GMMs in an agricultural setting in the presence of their legume host plants. Their persistence, as well as the impact on resident microbial groups were evaluated. An analysis of the ecological implications was also made by comparing the behavior of a GM Rhizobium isolated in foreign environment (allochthonous) with that of an indigenous strain of the same species, isolated from the release site (autochthonous) and tagged with the same genetic cassette.

\section{RESULTS}

\section{Release, persistence and impact of an allochthonous (non-native) GMM}

Prior to the release, an assessment of the indigenous microflora was carried out in the field of choice, yielding the following results, expressed as CFU.g $\mathrm{g}^{-1}$ (dry weight) of soil: aerobe bacteria total count: $2.06 \times 10^{7} \pm 5.00 \times 10^{5}$ (means of three field plot replicates \pm SD); fungi: $2.19 \times$ $10^{4} \pm 8.84 \times 10^{2}$; streptomyces: $2.69 \times 10^{6} \pm 1.86 \times 10^{6}$; fluorescent pseudomonads: $5.63 \times 10^{4} \pm 4.42 \times 10^{4}$; sporeforming bacteria: $2.17 \times 10^{6} \pm 2.15 \times 10^{5}$; Rhizobium group: $8.88 \times 10^{5} \pm 5.30 \times 10^{4}$. Besides scoring the soil rhizobial population by congo red-negative $\mathrm{CFU}$ counts on YMA, we performed pre-release MPN assessments for $R$. leguminosarum bv. viciae, $R$. leguminosarum bv. trifolii, Sinorhizobium meliloti and Bradyrhizobium japonicum, which gave, respectively, $5.2 \times 10^{3}, 2.8 \times 10^{2}$, $2.8 \times 10^{4}, 3.0 \times 10^{1}$ cells per gram of soil dry weight. Subsequently, the three previously described GMM derivatives of Rhizobium leguminosarum bv. viciae 1003 were released. These are strains $1110,1111,1112$, that carry $\mathrm{Hg}$ resistance and lac $\mathrm{Z}$ driven by a strong synthetic promoter, and that had been previously monitored in microcosm trials (Corich et al., 1996). Amounts of cells inoculated per seed were calculated as colony forming units per $\mathrm{mL}$ of inoculum suspension. The results are the following: strain 1003: $6.35 \times 10^{6} \pm 9.19 \times 10^{5}$; strain 1110: $5.45 \times 10^{6} \pm 1.20 \times 10^{5} ;$ strain $1111: 2.40 \times 10^{6} \pm 1.98 \times$ $10^{5}$; strain 1112: $6.45 \times 10^{6} \pm 3.54 \times 10^{4}$. Plating on media containing $\mathrm{X}-\mathrm{Gal}$ allowed estimation of the possible loss of the introduced $\beta$-galactosidase marker at the moment of inoculation. Revertants, consisting in the fraction of cells having lost the trait, were observed only in strain 1111 constitutively-expressing lac $Z$, and amounted to $4.20 \times 10^{5} \pm 4.24 \times 10^{4}$ of the above total cells. The use of such an unstable construct was envisaged as a negative control for its more stable versions (strains 1111 and 1112). The first sampling to monitor released bacteria was performed 10 days after sowing at the time of pea shoot emergence. Root development was already profuse and allowed rhizospheric soil isolation. The results showed a good initial colonization of the rhizosphere, and gave the following counts expressed as CFU.g ${ }^{-1}$ of soil dry weight; strain $1003(\mathrm{wt}): 4.68 \times 10^{4} \pm 2.26 \times 10^{4}$; strain 1110: $6.72 \times 10^{5} \pm 5.76 \times 10^{5}$; strain 1111: $1.28 \times 10^{6} \pm 8.95 \times 10^{5}$; strain 1112: $2.15 \times 10^{5} \pm$ $5.76 \times 10^{4}$. Concerning the three GMM strains, their revertants having lost the lacZ marker were observed at a detectable level only for strain 1111, in which they were $2.83 \times 10^{5} \pm 2.49 \times 10^{5}$, equal to about $22 \%$.

In terms of genetic stability, as expected, strain 1111, which bore the plasmid with the constitutively (over)expressed lac $Z$ construct showed fast plasmid loss, leading to revertants that account for a one-log decrease of the GMM. On the contrary, both strain 1110, which bore an identical plasmid differing only by the presence of the lac operator, and strain 1112 with the chromosomally-inserted version of the same genes, maintained their phenotype. The GMM presence in 
Long term evaluation of GM rhizobia

Table 1. Bacterial strains and plasmids.

\begin{tabular}{|c|c|c|}
\hline Strains & Relevant traits & Source or reference \\
\hline \multicolumn{3}{|c|}{ R. leguminosarum bv. viciae } \\
\hline 1003 & wild type (The Netherlands), rif $^{\mathrm{r}}$ & Corich et al., 1996 \\
\hline 1110 & 1003 pDG3, $\mathrm{Hg}^{\mathrm{r}} / \mathrm{lac} \mathrm{Z}++$ & Corich et al., 1996 \\
\hline 1111 & 1003 pDG4, $\mathrm{Hg}^{\mathrm{r}} / \mathrm{lacZ}+++$ (constitutive) & Corich et al., 1996 \\
\hline 1112 & 1003:: $\mathrm{Hg}^{\mathrm{r}} / \mathrm{lacZ}_{++}$ & Corich et al., 1996 \\
\hline Agri10 & wild type (Italy) rif ${ }^{\mathrm{T}}$ & this work \\
\hline 1114 & Agri10 pDG3, $\mathrm{Hg}^{\mathrm{r}} / \mathrm{lacZ}++$ & this work \\
\hline $\mathrm{Nb} 1$ & Wild type (England) & J. Beringer \\
\hline
\end{tabular}

Escherichia coli

JM 109 pDG3

donor for conjugation of pDG3

Corich et al., 1996

HB101 pRK2013

helper for conjugation of pDG3

Figurski and Helinski, 1979

Plasmids

pDG3 IncQ, $\mathrm{Hg}^{\mathrm{r}}, \mathrm{lacI}^{\mathrm{q}} / \mathrm{syn}$ thetic promoter/lacO/lacZ (IPTG-inducible) Giacomini et al., 1994

pDG4 IncQ, $\mathrm{Hg}^{\mathrm{r}}, \operatorname{lacI}^{\mathrm{q}} /$ synthetic promoter/lacZ (constitutively expressed) Giacomini et al., 1994

rif ${ }^{\mathrm{r}}$ : Rifampicin-resistant; lacZ: $\beta$-galactosidase gene; $\mathrm{Hg}^{\mathrm{r}}$ : mercury resistance; IncQ: incompatibility group Q; lac $^{\mathrm{q}}$ : lactose operon repressor.

the rhizosphere was monitored again 50 days after sowing and, at this stage, all strains had already dropped below the detection limit allowed by plate counts $\left(<10^{1}\right.$ CFU. ${ }^{-1}$ soil dry weight). Both the wild-type and the three types of GMMs had undergone the same rapid decrease, which was presumably due to the low fitness of their background strain with respect to the new environment. In fact, an analysis of the root nodule content from the same plants, carried out at 50 days after sowing, on about 1200 nodules (300 per each of the four treatments), showed an occupancy averaging $0.67 \%$ and not exceeding $1.7 \%$, which confirmed the low competitiveness of the strains. In detail, strain 1003 was found in two nodules, strain 1110 in none, strain 1111 in one nodule and strain 1112 in five nodules.

In addition, this effect observed in field conditions is not due to an intrinsically poor efficiency of all strains derived from 1003, since in axenic nodulation trials with autoclaved soil, each of them had proven able to nodulate peas profusely, indicating that this aspect of symbiotic performance was not affected by the genetic modification (data not shown). Lateral spread was negligible, as the analysis of another 650 nodules from the trap pea plants belt surrounding the plots did not yield strains carrying the phenotypic markers of the released ones. The fate of the released GMMs was further checked five months after release in a greenhouse study with soil gathered from the release site, by both selective plating and nodulation tests with faba bean and pea. No residual nodulating GMMs were rescued.
The disappearance of the GMMs was tested and confirmed one year after release, by re-sowing peas on some of the plots previously inoculated with strain 1112, which had given the highest values of persistence and nodulation. When the nodule content was analyzed, no GMMs could be reisolated.

Thirty months after the release, the possible residual presence of GMM DNA in soil was tested by PCR amplification using two primers designed to detect the lacmer gene cassette, thus targeting specifically the released strain. The efficiency of the method had been successfully tested on soil freshly supplemented with serially diluted suspensions of the GMM of choice. The field soil in which strain 1112 was released gave negative results, confirming the descent below detection of the GMM and of its recombinant DNA. The detection limits of PCR approaches to track released GM rhizobia have been addressed and range between 20 and 300 culturable cells per gram, depending on the tagged gene (Cullen et al., 1998).

As scheduled, the possible impact of released GMMs on resident microbiota was assayed by culturable colony counts of selected groups 30 days after release, and is shown in Table 2. The period of 30 days was chosen as a compromise between a time not too far from release but sufficient to reveal induced changes. In order to extract possible significant differences between treatments, a one-way chi-square test for equal proportions was run. As explained, the variance (square of the standard deviation) in this data set was larger than the data 
Table 2. Allochthonous GMM impact: resident culturable microbiota in pea rhizosphere soil assessed 30 days after the first GMM release.

\begin{tabular}{lcccccc}
\hline \hline & Bare soil control & Plant control & $\begin{array}{c}\text { Plants inoculated } \\
\text { with strain 1003 }\end{array}$ & $\begin{array}{c}\text { Plants inoculated } \\
\text { with strain 1110 }\end{array}$ & $\begin{array}{c}\text { Plant inoculated } \\
\text { with strain 1111 }\end{array}$ & $\begin{array}{c}\text { Plant inoculated } \\
\text { with strain 1112 }\end{array}$ \\
\hline Total bacteria & $2.19 \times 10^{7}$ & $1.28 \times 10^{8 \mathrm{a}}$ & $1.86 \times 10^{8 \mathrm{a}}$ & $9.69 \times 10^{7 \mathrm{a}}$ & $8.21 \times 10^{7 \mathrm{a}}$ & $2.19 \times 10^{8 \mathrm{a}}$ \\
& $\pm 7.95 \times 10^{5}$ & $\pm 1.21 \times 10^{7}$ & $\pm 3.24 \times 10^{7}$ & $\pm 2.87 \times 10^{7}$ & $\pm 1.76 \times 10^{6}$ & $\pm 1.39 \times 10^{7}$ \\
Fungi & $2.42 \times 10^{4}$ & $1.67 \times 10^{5}$ & $3.98 \times 10^{5}$ & $1.56 \times 10^{5}$ & $2.05 \times 10^{5}$ & $2.06 \times 10^{5}$ \\
& $\pm 7.95 \times 10^{2}$ & $\pm 8.23 \times 10^{4}$ & $\pm 5.63 \times 10^{4}$ & $\pm 8.84 \times 10^{4}$ & $\pm 6.16 \times 10^{4}$ & $\pm 2.78 \times 10^{4}$ \\
Fluorescent & $2.70 \times 10^{4}$ & $1.71 \times 10^{6}$ & $2.64 \times 10^{6}$ & $1.02 \times 10^{6}$ & $1.41 \times 10^{6}$ & $4.53 \times 10^{6}$ \\
Pseudomonads & $\pm 1.27 \times 10^{4}$ & $\pm 6.53 \times 10^{5}$ & $\pm 2.11 \times 10^{5}$ & $\pm 3.31 \times 10^{4}$ & $\pm 8.79 \times 10^{3}$ & $\pm 3.32 \times 10^{6}$ \\
Spore-forming & $7.87 \times 10^{6}$ & $3.42 \times 10^{6}$ & $6.32 \times 10^{6}$ & $4.22 \times 10^{6}$ & $5.91 \times 10^{6}$ & $3.63 \times 10^{6}$ \\
Bacteria & $\pm 3.18 \times 10^{6}$ & $\pm 1.21 \times 10^{6}$ & $\pm 1.48 \times 10^{6}$ & $\pm 1.77 \times 10^{6}$ & $\pm 4.40 \times 10^{5}$ & $\pm 9.72 \times 10^{5}$ \\
Rhizobia & $1.97 \times 10^{5}$ & $1.42 \times 10^{7 \mathrm{~b}}$ & $3.44 \times 10^{7 \mathrm{~b}}$ & $1.24 \times 10^{7 \mathrm{~b}}$ & $1.11 \times 10^{7 \mathrm{~b}}$ & $4.24 \times 10^{7 \mathrm{~b}}$ \\
& $\pm 3.98 \times 10^{4}$ & $\pm 3.68 \times 10^{6}$ & $\pm 1.15 \times 10^{7}$ & $\pm 3.64 \times 10^{6}$ & $\pm 6.16 \times 10^{5}$ & $\pm 3.82 \times 10^{6}$ \\
\hline
\end{tabular}

Data are expressed as CFU.g ${ }^{-1}$ (dry weight) of rhizosphere soil.

Values labelled with the same letter indicate data used for the analysis of a given variable ( ${ }^{\mathrm{a}}$ total bacteria, ${ }^{\mathrm{b}}$ rhizobia).

Significant differences (FREQ procedure) arise for the two variables "total bacteria" $(\mathrm{P}=0.0495)$ and "rhizobia" $(\mathrm{P}=0.0092)$ upon

applying a one-way chi-square test for equal proportions run within all the plant plots data on the fourth root of the raw data.

averages; therefore the analysis called for the appropriate transformation. As the data spanned several orders of magnitude the fourth root was elected as the most suitable one. The unaveraged raw data were used, and the significance tested in two assemblies, the first including also the bare soil, in which case all groups except fungi and spore-forming bacteria gave significant differences. These can be explained by the simple plant effect. Thus in the second data assembly we omitted the soil control and recorded a barely significant difference for the total bacteria $(P=0.0495)$, and a highly significant difference only for the rhizobia group $(\mathrm{P}=0.0092)$, which is in part consistent with their inoculation. As rhizobia are also a (minor) portion of the total bacterial count, the slight significance of the latter is also in line with such rhizobial fluctuation.

\section{Release, persistence and impact of an autochthonous (native) GMM}

Having witnessed the fast disappearance of rhizobia whose background strain (1003, originating from northern Europe) was not isolated from the same zone chosen for the release, we inserted the same genetic modifications into a Rhizobium indigenous to the site, and compared its behavior with that of the foreign GMMs. In order to enhance and bring above detection limits any possible impact of the GMM, we used a very competitive native strain, namely the one that had proven able to occupy most of the nodules on two different kinds of host plants grown in the same soil. The identification and isolation of this dominant candidate was done by com-
Table 3. Frequencies of unique DAF3-amplified RAPD fingerprints of $R$. leguminosarum isolated from nodules of pea or faba bean after the first GMM release.

\begin{tabular}{lcc}
\hline \hline RAPD Profiles & Pea (250 nodules) & Faba bean (32 nodules) \\
\hline Profile \#1 & $\mathbf{5 3 . 8 \%}$ & $\mathbf{4 4 \%}$ \\
Profile \#2 & $9.7 \%$ & $13 \%$ \\
Profile \#3 & $9.3 \%$ & $19 \%$ \\
Profile \#4 & $10.9 \%$ & $6 \%$ \\
Profile \#5 & $1.2 \%$ & $9 \%$ \\
Profiles \#6 to \#33 & $<1 \%$ & n.d. \\
\hline
\end{tabular}

n.d.: Not determined.

paring the RAPD electrophoretic profiles of 250 isolates from pea nodules, and of 32 isolates from faba bean. The primer of choice was the decamer DAF3 (Tichy and Simon, 1994). Thirty-three different profiles were detected among the symbionts of the pea host, while a total of nine profiles were enumerated from the smaller sample of faba bean nodules. The percentage at which the five most abundant cases occur in both hosts, is shown in Table 3.

Most profiles (\#6 to \#33), accounting for $15 \%$ of the pea nodule total occupancies, were found not more than once. At least five profiles were found in both host plants. Their respective frequency was in some cases highly variable. For example, such is the case of profile \#5, observed in less than $1 \%$ of the pea cases, but accounting for $9 \%$ of the faba bean isolates. Nevertheless, the most abundant profile was the same for both plants. Profile \#1, present in $54 \%$ and $44 \%$ of pea and faba bean nodules, respectively, was therefore selected as the dominant, symbiotically 
Long term evaluation of GM rhizobia

Table 4. Autochthonous GMM release. Persistence of the wild-type and GMM strains, in plots sown with pea or faba bean, or amended with lactose in substitution for the host plant.

\begin{tabular}{lccc}
\hline \hline Strain & Sampled material & 15 days after release & 50 days after release \\
\hline Agri10 & Pea rhizosphere & $6.41 \times 10^{6} \pm 3.48 \times 10^{6}$ & $3.97 \times 10^{6} \pm 4.29 \times 10^{5}$ \\
& Faba bean rhizosphere & $5.35 \times 10^{6} \pm 1.71 \times 10^{6}$ & $3.63 \times 10^{6} \pm 2.15 \times 10^{5}$ \\
& Soil & $3.87 \times 10^{4} \pm 1.30 \times 10^{4}$ & $1.16 \times 10^{4} \pm 1.29 \times 10^{3}$ \\
& Soil + lactose & $2.92 \times 10^{4} \pm 1.49 \times 10^{3}$ & $1.07 \times 10^{5} \pm 2.13 \times 10^{4}$ \\
1114 & Pea rhizosphere & $3.43 \times 10^{6} \pm 6.80 \times 10^{5}$ & $1.17 \times 10^{6} \pm 1.57 \times 10^{5}$ \\
& Faba bean rhizosphere & $2.09 \times 10^{6} \pm 9.47 \times 10^{5}$ & $3.70 \times 10^{5} \pm 8.83 \times 10^{4}$ \\
& Soil & $3.45 \times 10^{3} \pm 9.37 \times 10^{2}$ & $1.34 \times 10^{4} \pm 3.15 \times 10^{3}$ \\
& Soil + lactose & $2.45 \times 10^{4} \pm 5.06 \times 10^{3}$ & $1.56 \times 10^{4} \pm 4.75 \times 10^{3}$ \\
\hline
\end{tabular}

proficient, $R$. leguminosarum bv. viciae in the soils of the Legnaro experimental station. This background was considered to be the best example of high local adaptation, to be compared to the performance recorded with strains derived from strain 1003, whose low fitness could have been due to the different habitat of origin. The dominant Rhizobium strain carries four large plasmids ranging from 180 to $550 \mathrm{Md}$ (data not shown). A spontaneous rifampicin-resistant derivative of the strain was obtained (Agri10), from which a genetically modified derivative was constructed by conjugal transfer of plasmid pDG3, carrying the mercury-lactose gene cassette, giving rise to strain 1114. This construct is thus equivalent to the previously released strain 1110, with the difference of an indigenous background. Strain Agri 10 was also pre-tested in pot nodulation tests on faba bean grown in the soil of the future release, and compared to another control strain, $\mathrm{Nb} 1$, kindly provided by John Beringer, which was a dominant nodule occupant for peas in its British isolation site. After 30 days, strain Agri 10, inoculated using $1 \times 10^{6}$ cells per seed, was found in $88 \%$ of Vicia faba nodules, while $\mathrm{Nb} 1$, in separate pots, invaded no more than $10 \%$. This result further emphasizes that nodulation is quantitatively not determined by universal competitiveness, but rather by the degree of local adaptation to soil and host.

As the new release was scheduled for the fall season, requiring an overwintering pea cultivar, strains Agri 10 and 1114 were tested again in pot nodulation tests, using an inoculum of $8 \times 10^{6}$, and $6 \times 10^{6}$ cells per seed respectively, applied to two different winter pea cultivars: Rampicante Telefono, and Mezzarama Senatore. The performance on each cultivar was different in terms of nodulation and the genetic stability of the GMM. Cultivar Rampicante Telefono had $20 \%$ of nodules occupied by strain Agri10 (wt), or $40 \%$ by strain 1114 . The marker stability (percentage of isolates maintaining the introduced trait) of the latter strain after nodulation was $85 \%$. Cultivar Mezzarama Senatore had 24\% of nodules occupied by strain Agri10 (wt), or $53 \%$ by strain 1114 . The marker stability of the latter after nodulation was $100 \%$. This cultivar was selected as host for the new field release, which took place on October 16th 1995. The different plasmid stability observed is presumably due to differential pressure that each host cultivar can exert during the fast bacterial replication occurring in the infection stage.

The operations followed the protocol described for the first campaign, with the modification of a higher titer of the inoculum suspension, providing $1.72 \times 10^{7} \pm 3.06 \times$ $10^{6}$ and $1.94 \times 10^{7} \pm 2.20 \times 10^{6}$ cells per seed, for strains Agri 10 and 1114 respectively. The higher amounts were used because of the less favorable seasonal parameters. In comparison with the first release, although the number of strains was reduced to two, the number of variables was increased by using two host plants, pea and faba bean, and by testing the effect of enhanced selective conditions for the GMM in certain selected plots. In this respect, considering that the gene cassette conferred a very high $\beta$-galactosidase activity (Corich et al., 1996; Giacomini et al., 1994), we amended individual field plots by sprinkling 4 liters of a 5\% lactose solution per square meter. On these plots, the strains were released without host plants. A further control consisted of plots of bare soil not supplemented with lactose. The experimental scheme is summarized in Table 4, in which the results of two subsequent monitoring platings, at 15 and 50 days after release, are shown. Both the parental and the GMM strain showed a persistence about $2 \log$ higher than that seen for strain 1003 in the previous release. Their colonization of soil and rhizosphere appeared to be stable 50 days from sowing. The genetic stability of the GMM as judged by maintenance of marker phenotypes in 100 colonies from the different treatments, ranged from 96.5 to $100 \%$, with no differences between the day 15 and day 50 sampling times. As regards the effects on indigenous microbiota, the data were gathered at the same time intervals, and are shown in Table 5. The Chi-square test verifying the hypothesis of equal proportions was run as in the case of the first release. Again the soil and plant assemblies were 
Table 5. Autochthonous GMM impact: resident culturable microbiota in pea rhizosphere soil assessed 50 days after strain release.

\begin{tabular}{|c|c|c|c|}
\hline & not inoculated & Agri10 & 1114 \\
\hline \multicolumn{4}{|l|}{ Faba bean } \\
\hline Bacterial total count & $8.71 \times 10^{7} \pm 1.97 \times 10^{7} \mathrm{a}$ & $1.73 \times 10^{8} \pm 8.58 \times 10^{7} \mathrm{a}$ & $1.52 \times 10^{8} \pm 3.51 \times 10^{7} \mathrm{a}$ \\
\hline fungi & $5.12 \times 10^{4} \pm 6.80 \times 10^{3}$ & $6.45 \times 10^{4} \pm 1.67 \times 10^{4}$ & $1.35 \times 10^{5} \pm 2.40 \times 10^{4}$ \\
\hline Streptomyces & n.d. & n.d. & n.d. \\
\hline Fluorescent pseudomonads & $5.55 \times 10^{5} \pm 2.85 \times 10^{5} \mathrm{~b}$ & $2.00 \times 10^{6} \pm 9.58 \times 10^{5} \mathrm{~b}$ & $1.27 \times 10^{6} \pm 2.40 \times 10^{5} \mathrm{~b}$ \\
\hline Spore-forming bacteria & $4.58 \times 10^{6} \pm 1.15 \times 10^{6}$ & $5.16 \times 10^{6} \pm 9.94 \times 10^{5}$ & $1.49 \times 10^{7} \pm 8.25 \times 10^{6}$ \\
\hline Rhizobia & $4.03 \times 10^{6} \pm 1.24 \times 10^{6} \mathrm{c}$ & $1.10 \times 10^{7} \pm 6.01 \times 10^{6} \mathrm{c}$ & $9.36 \times 10^{6} \pm 2.87 \times 10^{6} \mathrm{c}$ \\
\hline \multicolumn{4}{|l|}{ Pea } \\
\hline Bacterial total count & $1.61 \times 10^{8} \pm 2.58 \times 10^{7} \mathrm{~d}$ & $1.73 \times 10^{8} \pm 5.45 \times 10^{7} \mathrm{~d}$ & $1.54 \times 10^{8} \pm 3.65 \times 10^{7} \mathrm{~d}$ \\
\hline fungi & $1.39 \times 10^{5} \pm 4.68 \times 10^{3}$ & $7.69 \times 10^{4} \pm 4.62 \times 10^{4}$ & $9.21 \times 10^{4} \pm 1.60 \times 10^{4}$ \\
\hline Streptomyces & n.d. & n.d. & n.d. \\
\hline Fluorescent pseudomonads & $1.13 \times 10^{6} \pm 1.72 \times 10^{5} \mathrm{e}$ & $5.77 \times 10^{6} \pm 1.39 \times 10^{6} \mathrm{e}$ & $3.06 \times 10^{6} \pm 8.47 \times 10^{5} \mathrm{e}$ \\
\hline Spore-forming bacteria & $6.79 \times 10^{6} \pm 1.17 \times 10^{6} \mathrm{f}$ & $6.97 \times 10^{6} \pm 1.11 \times 10^{6} \mathrm{f}$ & $6.05 \times 10^{6} \pm 3.25 \times 10^{6} \mathrm{f}$ \\
\hline Rhizobia & $2.32 \times 10^{7} \pm 6.62 \times 10^{6} \mathrm{~g}$ & $4.27 \times 10^{7} \pm 1.88 \times 10^{7} \mathrm{~g}$ & $2.04 \times 10^{7} \pm 4.74 \times 10^{6} \mathrm{~g}$ \\
\hline \multicolumn{4}{|l|}{ Soil } \\
\hline Bacterial total count & $3.30 \times 10^{7} \pm 1.55 \times 10^{7}$ & $3.49 \times 10^{7} \pm 7.03 \times 10^{6}$ & $3.93 \times 10^{7} \pm 1.66 \times 10^{7}$ \\
\hline fungi & $8.31 \times 10^{4} \pm 1.48 \times 10^{4}$ & $8.43 \times 10^{4} \pm 4.60 \times 10^{3}$ & $5.03 \times 10^{4} \pm 1.41 \times 10^{4}$ \\
\hline Streptomyces & $3.97 \times 10^{6} \pm 9.57 \times 10^{5}$ & $3.41 \times 10^{6} \pm 1.03 \times 10^{6}$ & $2.70 \times 10^{6} \pm 1.56 \times 10^{6}$ \\
\hline Fluorescent pseudomonads & $8.94 \times 10^{3} \pm 1.08 \times 10^{3}$ & $4.73 \times 10^{3} \pm 1.35 \times 10^{3}$ & $4.65 \times 10^{3} \pm 1.09 \times 10^{3}$ \\
\hline Spore-forming bacteria & $1.84 \times 10^{7} \pm 8.15 \times 10^{6}$ & $1.75 \times 10^{7} \pm 4.11 \times 10^{6}$ & $2.28 \times 10^{7} \pm 8.96 \times 10^{6}$ \\
\hline Rhizobia & $6.02 \times 10^{5} \pm 8.77 \times 10^{4} \mathrm{~h}$ & $5.58 \times 10^{5} \pm 6.55 \times 10^{4} \mathrm{~h}$ & $3.51 \times 10^{5} \pm 4.80 \times 10^{4} \mathrm{~h}$ \\
\hline \multicolumn{4}{|l|}{ Soil + lactose } \\
\hline Bacterial total count & $3.23 \times 10^{7} \pm 6.28 \times 10^{6}$ & $5.17 \times 10^{7} \pm 3.56 \times 10^{7}$ & $2.81 \times 10^{7} \pm 4.82 \times 10^{6}$ \\
\hline fungi & $6.81 \times 10^{4} \pm 1.75 \times 10^{4}$ & $5.17 \times 10^{4} \pm 9.27 \times 10^{3}$ & $4.46 \times 10^{4} \pm 7.72 \times 10^{3}$ \\
\hline Streptomyces & $2.94 \times 10^{6} \pm 3.32 \times 10^{5}$ & $2.21 \times 10^{6} \pm 3.82 \times 10^{5}$ & $1.96 \times 10^{6} \pm 6.86 \times 10^{5}$ \\
\hline Fluorescent pseudomonads & $4.57 \times 10^{3} \pm 1.28 \times 10^{3}$ & $3.27 \times 10^{3} \pm 5.35 \times 10^{2}$ & $1.29 \times 10^{3} \pm 4.30 \times 10^{2}$ \\
\hline Spore-forming bacteria & $2.11 \times 10^{7} \pm 3.95 \times 10^{6}$ & $1.63 \times 10^{7} \pm 6.26 \times 10^{6}$ & $1.96 \times 10^{7} \pm 6.32 \times 10^{6}$ \\
\hline Rhizobia & $2.11 \times 10^{6} \pm 4.75 \times 10^{5} \mathrm{~h}$ & $1.94 \times 10^{6} \pm 6.53 \times 10^{5} \mathrm{~h}$ & $1.96 \times 10^{6} \pm 6.82 \times 10^{5} \mathrm{~h}$ \\
\hline
\end{tabular}

Values labelled with the same letter indicate data used for the analysis of a given variable. a: $\mathrm{P}=0.0243, \mathrm{~b}: \mathrm{P}=0.056, \mathrm{c}: \mathrm{P}=0.0497$, d: $\mathrm{P}=0.0474$, e: $\mathrm{P}=0.0073$, f: $\mathrm{P}=0.0024$; $\mathrm{g}: \mathrm{P}=0.0013$, $\mathrm{h}: \mathrm{P}=0.0107$, report the $\mathrm{P}$ values obtained upon a one-way chi square test for equal proportions run within the three column plots of the same plant (V. faba a-c; P. sativum d-g) or within all the soil plots (h) on the fourth root of the raw data. n.d.: Not determined.

tested both in combination and separately. When testing differences within the faba bean plots, significant values arose for total bacteria, and borderline values for rhizobia and pseudomonads. For peas, a higher level of significance involved total bacteria, rhizobia, pseudomonads, and spore-forming bacteria. The proportions of the latter appear reduced, giving the indication of a possible negative impact, which was however associated with both the GMM strain 1114 and its non-GMM control Agri10.

In order to refine the information relative to the effects on closely related organisms, besides the congo red YMA plate counts of overall rhizobia, we determined the most probable numbers of Sinorhizobium meliloti by alfalfa nodulation tests with dilution series of the rhizosphere soil from pea and faba bean. The results (not shown) indicate the absence of effect. The low numbers, comparable to, or even lower than those previously obtained for these soils, also reveal that the two heterologous host plants (specific for the viciae biovar of rhizobia) did not seem to have a stimulatory rhizosphere effect on S. meliloti.

\section{Self-impact: the effects in nature of an autochthonous GMM on its own wild-type}

There is however one soil micro-organism on which the introduction of the released strains Agri 10 and 1114 was 
inevitably bound to have an effect. That is their natural wild-type parental strain. Our setup made it possible to evaluate the outcome of an encounter between the inoculated strains and their indigenous, hitherto dominant, equivalent (the wild-type parent). The ecological question behind such analysis was whether a massively released, competitive Rhizobium would have displaced its resident counterpart, along with other natural strains, or whether, on the contrary, the plant would have nevertheless imposed the preservation of a share for diverse rhizobial strains in terms of nodule occupancy.

The GMM effect on its parent version could have been exerted mainly as competition for nodulation, which was the strain's most evident feature. In order to assess to what extent inoculating plants with an amount of $6 \times 10^{6}$ cells per seed of strain 1114 would result in substitutive out-competition or, instead, in an additive effect, 60 faba bean nodules were screened for strain identity by RAPD fingerprinting and marker resistance. In the uninoculated control the parent dominant strain occupied $40 \%$ of the nodules. The remaining $60 \%$ was split between several (about 15) different natural strains, each present at low frequencies ranging from 0.5 to $5 \%$. In the inoculated plots, the GMM derivative took $50 \%$ of the nodules, its resident parent was still able to nodulate $15 \%$, (i.e. one third of the remaining 50\%), while the final 35\% were occupied by the other natural profiles.

\section{Long-term persistence of the GMM authochtonous strain 1114}

The survival of the introduced GM strain 1114 was assessed by periodical monitoring, which was extended in particular in nine soil plots, in triplicate replicates, constituting the three above described treatments (inoculum on pea seed, or on bare soil, or on bare soil amended with lactose). Analyses were carried out through a period of nine years (1995-2004), i.e. until the last detectable GMM cell had disappeared from all plots. Figure 1 shows the GMM strain dynamics expressed as rifampicin and mercury resistant CFUs per gram of soil dry weight. The first three data sets $(15,50$, and 150 days after inoculation) refer to the release season itself. In these, the values come either from rhizosphere soil (pea-sown plots) or from plain soil (plots with bare soil or bare soil plus lactose). In the subsequent period, in order to keep rhizobia within monitoring range, we planted peas again in the spring of 1996, 1997, and 1999. This operation was intended to provide to all plots periodical bursts of enhancement for the rhizobia. The plants were meant to act as general amplifiers for $R$. leguminosarum populations in all plots. The practice made it possible to sustain detectability of GMM strains through time, and to follow their dynamics in relation to the three initial differential treatments. The data from day 210 onwards are therefore all from pea rhizosphere soil, including the plots in which the strain had initially been released on soil without plants. This plant-enhanced monitoring strategy also allowed assessment of the extent of nodulation by the persistent GMM.

When comparing plots where strain 1114 was released with peas with those where it was dispensed in soil without plants, it is clear that the initial plant effect was clearly supportive. The strain in bare soil showed lower values, and even when plants were added in the following seasons it could never be rescued back to numbers comparable to those found in the plot where pea was present right from the beginning. During the fourth year, the numbers in the bare soil plot fell below the detection limit. A very interesting result was observed in the three replicates of the plot where unsown soil had been amended with lactose (4 L.m $\mathrm{m}^{-2}$ of a $5 \%$ lactose solution). This treatment was intended to test the possible selective advantages given by a strong $\beta$-galactosidase activity, which was part of our introduced marker gene cassette. In fact, lac $Z$ in $\mathrm{pDG} 3$ is driven by a synthetic consensus promoter that confers a greater than hundred-fold increase over the basal activity level (Giacomini et al., 1994). A remarkably positive effect was observed, as the strain initially suffered only a moderate decrease compared to the dramatic one seen in the adjacent plain bare soil. Rhizobia of strain 1114 were thus able to overwinter at stable numbers in soil, i.e. above $10^{4}$ per gram, which is just one log lower than the numbers obtained at the same date around aged pea roots in the plant plot (Fig. 1). The recovery promoted by plants in the following season boosted the rhizobia from the lactose-amended plots to numbers far higher than those that had survived in the presence of plants. Also, the sampling of the two following dates demonstrated that even three years later, the initial nutritional advantage allowed strain 1114 to survive in the long run much better than having been exposed to its symbiotic host.

The decline below detection levels of the introduced GMM 1114 in the release site appears to have occurred between spring 1999 and summer 2002, at which stage a new round of pea cultivation and the analysis of 581 new nodules from the three treatments' plots did not produce any isolate with the lac-mer phenotypic markers of strain 1114. Interestingly, RAPD PCR typing of all isolates (Polone et al., in preparation) showed that even the original parent strain of Agri10 and 1114 was no longer dominant in the field, having dropped to $1.33 \%$ of the nodule occupancies. Therefore the disappearance of the GMM is also to be viewed as part of a general substitutional succession of rhizobial populations, which became evident in the seventh year after the initial assessment. In order to test for possible back-fluctuations and 


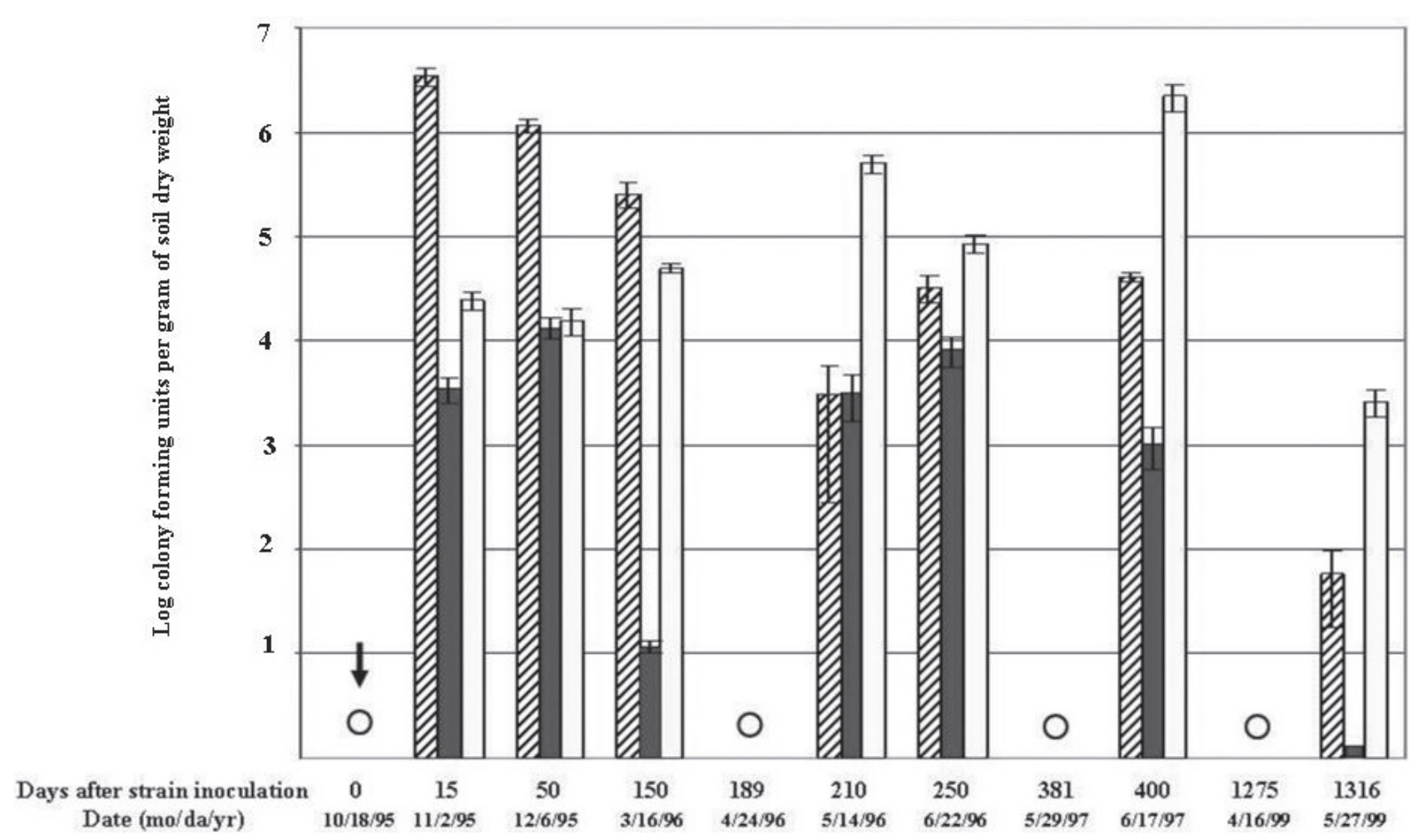

Figure 1. GMM dynamics through time. The Y-axis reports, in logarithmic scale, Rhizobium leguminosarum strain 1114 recoverable colony forming units that maintained rifampicin and $\mathrm{Hg}$ resistance markers. Data are expressed as the log of CFUs per gram of soil (dry weight) collected from the plots. Time data points are on the X-axis. The last monitored point, falling in the ninth year since release of strain 1114 (June 2004) was not plotted, since detectable GMM CFUs were no longer present in any of the plots. The arrow indicates the time of strain release. Open circles symbolize pea sowing. Histogram bars are means of values from three replicates. Hatched bars: initial release on pea seed. Solid bars: initial release on bare soil. Open bars: initial release on bare soil previously irrigated with a 5\% lactose solution. The last value for bare soil (solid middle bar at day 1316) is not drawn to scale; it corresponds to the fall of the CFUs below the detection limit for this plot.

persistence in non-symbiotic conditions, peas were sown and the rhizosphere in the three treatments was again sampled in the tenth year since release, in late spring 2004. Strain 1114 was not detectable.

Nodulation was also monitored through the years (Tab. 6). Interestingly, the GMM, which had performed competitively on the plants where it was released $(55 \%$ on pea and $52 \%$ on faba bean), persisted the following spring in a relatively competitive fashion. At that time it occupied $44 \%$ of the spring cultivar nodules in the plot where peas were previously present, $36 \%$ of nodules of plants sown in the soil-lactose plots, and $11.7 \%$ of nodules in the previously bare soil plots. However, while the introduced plasmid was almost fully retained (99\%) during the first winter nodulation, when peas were sown again in all plots in the subsequent years, its stability showed a marked decrease, as all rif ${ }^{\mathrm{T}}$ cases isolated from nodules of the peas and bare soil plots, were devoid of pDG3 (as verified by the absence of mark- ers and by plasmid profiling). Only in the lactose plot could the plasmid still be found associated to $5 \%$ of the nodule-rescued rif $^{\mathrm{r}}$ colonies. The competitive contribution to nodulation by strain 1114 decreased in years in parallel with the drop of its rhizosphere persistence. Data from plants sown in the fourth year show that only in the plot initially amended with lactose were there still enough GMM cells to yield detectable pea nodulation, with a frequency of $0.5 \%$. No nodules from plants of the other plots contained the GMM strain. Nevertheless, despite the low nodule score, all these cases had retained the $\mathrm{LacZ} \mathrm{Hg}^{\mathrm{r}}$ plasmid. This may correspond to a strategy aiming at keeping the genes for heterotrophic survival (lacZ), throughout a period when the opportunity for host plant symbiosis was encountered only every other year.

Besides nodules, plasmid stability was assessed also in the isolates from bulk soil and rhizosphere soil. Interestingly, the introduced plasmid appeared practically stable (90-100\%), regardless the treatment and the time 
Table 6. Autochthonous GMM release: nodulation dynamics and post-nodulation genetic stability over a seven year time course. The percent nodule occupancy of the parental and GMM strain during periodical legume sowings after strain release is indicated. The plasmid stability \% (in italics) for the GMM strain is measured as marker presence in bacteria rescued from surface sterilized nodules.

\begin{tabular}{|c|c|c|c|c|c|c|}
\hline \multirow[b]{3}{*}{$\begin{array}{l}\text { Initial treatment of } \\
\text { plots (October 1995) }\end{array}$} & \multicolumn{6}{|c|}{ Strain } \\
\hline & \multicolumn{3}{|c|}{ Agri 10 (rif $^{\mathrm{r}}$ parental) } & \multicolumn{3}{|c|}{1114 (rif $^{\mathrm{r}} \mathrm{Hg}^{\mathrm{r}} \mathrm{lacZ}++$ GMM) } \\
\hline & Peas sown & Bare soil & Bare soil + lactose & Peas sown & Bare soil & Bare soil + lactose \\
\hline $\begin{array}{l}\text { Winter pea crop pre-flowering } \\
\text { (December 1995) }\end{array}$ & $67 \%$ & (no plants) & (no plants) & $55 \%(99 \%)$ & (no plants) & (no plants) \\
\hline $\begin{array}{l}\text { New pea crop pre-flowering } \\
\text { (May 1996) }\end{array}$ & $32 \%$ & $23 \%$ & $31 \%$ & $44 \%(0 \%)$ & $11.7 \%(0 \%)$ & $36 \%(5 \%)$ \\
\hline $\begin{array}{l}\text { New pea crop pre-flowering } \\
\text { (June 1997) }\end{array}$ & $0 \%$ & $0 \%$ & $0 \%$ & $0 \%$ & $0 \%$ & $3 \%(100 \%)$ \\
\hline $\begin{array}{l}\text { New pea crop pre-flowering } \\
\text { (May 1999) }\end{array}$ & n.d. & n.d. & n.d. & $0 \%$ & $0 \%$ & $0.5 \%(100 \%)$ \\
\hline $\begin{array}{l}\text { New pea crop pre-flowering } \\
\text { (June 2002) }\end{array}$ & n.d. & n.d. & n.d. & $0 \%$ & $0 \%$ & $0 \%$ \\
\hline
\end{tabular}

n.d.: Not determined.

from release, up to the last instance where strain 1114 was encountered (May 1999). This in-soil genetic stability is remarkably different from the one observed for the corresponding nodulating isolates described above, in which, already after the first spring round of symbiosis, only $0-5 \%$ of the nodule-associated 1114 had retained plasmid pDG3 (Tab. 6).

\section{DISCUSSION}

The first consideration regards the fate of the strain of foreign origin. Notwithstanding its proficiency in its land of isolation or in axenic soil, when released in our station its performance was poor, both in terms of symbiosis and persistence. The new environment and the competition with resident rhizobia appeared to severely affect its outcome. Moreover, the three GMM versions displayed differential stability of the markers, depending on the position of these within the genome and on their gene regulation. Such behavior confirms in soil the genetic stability we observed with the same strains within inoculant packages in the prior long-term (500 days) microcosm trial (Corich et al., 1996). Examples of variable persistence of GM rhizobia are found in the literature (Hirsch, 2004) and in some instances such behavior is site-dependent. An hitherto persistent strain of R. leguminosarum bv. viciae, carrying a transposon disappeared two weeks after release from an eutric cambisol in Dijon (Hirsch, 1996). A genetically modified strain of S. meliloti carrying an exogenous glucuronidase and increased expression of its proline dehydrogenase dropped by five orders of magnitude in five months in a spanish soil (Van Dillewijn et al., 2001). The low persistence of a released Rhizobium is not necessarily linked to its being genetically impaired. For example, a recA-minus derivative of $S$. meliloti showed a stability similar to that of its wild-type, as it declined from $10^{6}$ to $10^{4} \mathrm{cfu}^{\mathrm{c}} \mathrm{g}^{-1}$ of soil in two years time (Schwieger and Tebbe, 2000). Climatic conditions such as heavy rain after release negatively affect persistence (Hirsch, 1996), and so do cold winters, as shown in the boreal zone for GM R. galegae (Pitkajarvi et al., 2003). Besides survival, in terms of nodulation, released GM rhizobia, like all symbiotic inoculants, face the competition of indigenous members of the same species, as shown quantitatively for GM S. meliloti (Miethling and Tebbe, 2004).

Concerning impact, the following considerations can be made. While no major effect was expected by the poorly persisting allochthonous strain, on the contrary, the dominant indigenous one was in a better position to create potential disturbance. However, notwithstanding the ecological success that was maintained by the GMM derivative, neither its massive inoculation nor the presence of recombinant traits resulted in major perturbations on numbers of culturable soil inhabitants within the groups tested. The significance of some of the differences recorded is however informative of possible impacting interactions caused by rhizobial inoculants themselves (either GM or not) that should be elucidated better by studies at the qualitative level.

On the issue of impact, it must also be stressed that the genetic traits introduced were not of an inherently 
harmful nature. Moreover, the limited power of single point quantitative $\mathrm{CFU}$ counts is in itself a strategy prone to overlook many subtle changes. There are no examples in the literature of negative impacts due to GM rhizobia yet, while in some cases a beneficial effect on mycorrhizal formation has been recorded with GM S. meliloti improved for its nodulation competitiveness (Tobar et al., 1996).

The absence of a strong "self-impact" on the GMM's parental kin constitutes one of the interesting results stemming from these trials. An already dominant strain, even when further inoculated in high numbers, did not displace in a proportional manner either its parent or the other minority profiles from the final nodule score. Indeed the percentage of nodules cumulatively taken by the dominant parent plus its GMM version, reached 65\%. Within this figure the contribution of the original parent strain alone is $15 \%$. The remaining $35 \%$ of the nodules contained a series of strains with different profiles (about 13) each present with frequencies from 3 to $6 \%$. Therefore there was not a straight additive effect but rather a partial competitive substitution of the soil dominant strain by its massively inoculated counterpart. It is very interesting to note that such inoculum was able to substitute both its parent and the other rhizobia to the same extent, leading to a $25 \%$ decrease for each (from $40 \%$ to $15 \%$ for the wt parent and from $60 \%$ to $35 \%$ for the other profiles). From MPN data we also know that the efficient indigenous strain was part of a natural soil Rhizobium population of around $5.6 \times 10^{5}$ cells per gram of soil dry weight. Considering its success even when starting from these numbers, one could have expected that adding a large inoculum of its GMM derivative $\left(6 \times 10^{6}\right.$ cells per seed), would result in an overwhelming competitive effect. However, the analysis shows that even when saturated with a very infective strain the plants still ended up with a fair proportion of the nodules induced and invaded by a variety of resident, less competitive, $R$. leguminosarum bv. viciae strains. Moreover, a good share of nodules was still accessed by the soilborne dominant parent. This result provides insight into the general mechanisms ruling rhizobial competition for nodulation. It could be postulated that the plant may play an active role in controlling the strain diversity of the bacteria eventually admitted in its nodules, irrespective of their numbers in soil or rhizosphere. The phenomenon is in line with previous reports dealing with alfalfa rhizobia (Paffetti et al. 1998).

In the long term persistence analysis of strain 1114, we observe that the initial lactose supplementation was positively correlated with its survival in the plots. The effect appears superior also to that of an initial presence of the host. We observe that in terms of recoverable colony forming units up to four years after the release, trophic selection proved at least ten-fold more effective than plant host presence, and nearly a hundredfold superior when compared to totally neutral environmental conditions consisting in the bare soil neither sown with legumes nor supplemented with lactose. This effect is unlikely to be caused by persisting resource, as lactose is supposedly degraded shortly after supplementation, but rather by the lasting effect of its nutritional support to the lac-proficient populations during the first winter after release. The superior effect of lactose supplementation is possibly explained by the fact that lactose enrichment was diffused through the whole soil volume, while the pea rhizosphere effect was limited to the network explored by root paths. In surveys on genetically modified $S$. meliloti, although not endowed with extra catabolic genes, strain persistence was found positively correlated with soil organic matter content (Da and Deng, 2002). More specifically, the issue of ecological selectivity in relation to released GMMs has been thoroughly addressed by van Veen et al. (1997). The persistence of rhizobia bearing genetic modifications has been related to many factors mainly regarding soil type, presence of host legume and competing co-specific strains (Hagen et al., 1997). In relation to lactose, microcosm soil trials performed in pea rhizospheres with Pseudomonas fluorescens carrying lacZY, during a 21 days incubation, showed that the substrate could enhance the GMM recovery by 0.3 of a log unit (Naseby and Lynch, 1998).

Coming to the issue of genetic stability, we observed (Tab. 6) that the recombinant plasmid was lost rapidly upon nodulation, while being retained stably by the GMM persisting in the soil. However, this is compatible with our previous results on in- and ex-planta genetic stability; in our prior investigations (Corich et al., 2001a) we reported that introduced plasmids suffered high frequency losses during spring pea nodulation by $R$. leguminosarum bv. viciae, and were in contrast maintained by cells remaining in the rhizosphere. In another report (Corich et al., 2001b), focusing on large natural Rhizobium plasmids, we studied the extent of plasmid loss and deletion in relation to nodulation. Large natural plasmids were much more stable than small, introduced plasmid vectors. The phenomenon appeared to be linked to nodulation, since the same vectors were nearly $100 \%$ stable during in vitro growth for over 200 generations of the rhizobia. In the present paper we also noticed (Tab. 6) that in the winter pea (sown October 1995), nodulation did not affect plasmid stability. This suggests that possibly cultivar- or spring temperature-related effects may be playing a role in destabilizing introduced replicons during host invasion.

In conclusion, interesting lessons on Rhizobium environmental dynamics can be drawn from these data. A trophic gene-for-substrate advantage, even with a single 
instance of availability, can result in a long-term positive selection even stronger than that of plant symbiosis, and this can benefit future nodulation. Such knowledge is of prime interest for the design of improved agricultural inoculants and for strategies of competition versus indigenous strains.

A plasmid-curing effect, exerted particularly upon introduced replicons, during spring nodulation is confirmed.

Summarizing the effects on the assessment of environmental impact, we observe that, as far as our methods could reveal, neither the ecologically less fit GMM strain that was released first, nor the more adapted competitive autochthonous version, affected the microbiota in the site of introduction in ways that could be related to the genetic modification. Considering the nature of the released bacterial species, and the neutral incidence of the introduced genes in the chosen habitat, the absence of GMM-related impact is in line with the expectations. However, the small but statistically detectable alterations in the counts of some soil groups, observed particularly after the release of the locally dominant strain, indicate that a certain degree of impact on the soil communities can be exerted by the rhizobial inoculants themselves, irrespective of whether they are genetically modified or not.

\section{MATERIALS AND METHODS}

\section{Bacterial strains and growth conditions}

Strains are listed in Table 1. E. coli was grown at $37{ }^{\circ} \mathrm{C}$ on Luria Broth LB ( $1 \% \mathrm{NaCl}, 1 \%$ Bacto tryptone, $0.5 \%$ yeast extract). Rhizobia were routinely grown in Tryptone-Yeast, TY (Beringer, 1974) or Yeast Mannitol, YM (Vincent, 1970). When appropriate, media were supplemented with $30 \mu \mathrm{g} \cdot \mathrm{mL}^{-1}$ (E. coli) or $60 \mu \mathrm{g} \cdot \mathrm{mL}^{-1}$ (Rhizobium) of rifampicin, and 3-5 $\mu \mathrm{g} \cdot \mathrm{mL}^{-1}$ (E. coli) or $10 \mu \mathrm{g} \cdot \mathrm{mL}^{-1}$ (Rhizobium) of $\mathrm{HgCl}_{2}, 20 \mu \mathrm{g} \cdot \mathrm{mL}^{-1}$ isopropyl thiogalactoside (IPTG), and $20 \mu \mathrm{g} . \mathrm{mL}^{-1}$ bromo-chloroindolyl galactopiranoside (X-gal).

For the detection of indigenous soil culturable microbiota, different groups were selected with the following media and conditions. Aerobic bacterial population: Plate Count Agar (Difco, Detroit, Michigan) supplemented with $50 \mu \mathrm{g} \cdot \mathrm{mL}^{-1}$ cycloheximide; plates were incubated for 3 days at $28{ }^{\circ} \mathrm{C}$. Spore forming bacteria: after heating the soil suspensions at $80{ }^{\circ} \mathrm{C}$ for 10 minutes, these were plated on Nutrient Agar (Difco, Detroit, Michigan) supplemented with 5 g.L ${ }^{-1}$ glucose and $50 \mu \mathrm{g} . \mathrm{mL}^{-1}$ cycloheximide; plates were incubated for 3 days at $28{ }^{\circ} \mathrm{C}$. Microfungi: Potato Dextrose Agar pH 3.5 (Difco, Detroit, Michigan); plates were incubated for 3 days at $28{ }^{\circ}$ C. Streptomycetes: Complete Streptomyces Medium (CSM) (7 g.L . $^{-1}$ glycerol, 0.7 g.L -1 $^{-1}$ L-asparagine, 0.7 g.L $\mathrm{L}^{-1} \quad \mathrm{~K}_{2} \mathrm{HPO}_{4}, \mathrm{pH}$ 7); plates were incubated for 14 days at $28{ }^{\circ} \mathrm{C}$. Fluorescent pseudomonads: modified King's B medium $\left(20\right.$ g.L $\mathrm{L}^{-1}$ proteose peptone, 10 g.L. ${ }^{-1}$ glycerol, 1.5 g.L $\mathrm{L}^{-1} \mathrm{KH}_{2} \mathrm{PO}_{4}$, 1.5 g.L ${ }^{-1} \mathrm{MgSO}_{4} .7 \mathrm{H}_{2} 0, \mathrm{pH}$ 7.2), supplemented with $100 \mu \mathrm{g} . \mathrm{mL}^{-1}$ cycloheximide, $50 \mu \mathrm{g} . \mathrm{mL}^{-1}$ carbenicillin, $13 \mu \mathrm{g} . \mathrm{mL}^{-1}$ chloramphenicol; plates were incubated for 2 days at $28{ }^{\circ} \mathrm{C}$. Rhizobia: YM medium supplemented with $50 \mu \mathrm{g} \cdot \mathrm{mL}^{-1}$ cycloheximide and $25 \mu \mathrm{g} \cdot \mathrm{mL}^{-1}$ congo red; plates were incubated for 2 days at $28{ }^{\circ} \mathrm{C}$. Media were solidified with the addition of 16 g.L. $\mathrm{L}^{-1}$ agar.

\section{Nodulation tests in axenic soil}

Ten $\mathrm{kg}$ of soil from the release site were sieved and blended. The soil was subsequently sterilized under a vapor current by leaving it for 1 hour in an unpressurized autoclave at $100{ }^{\circ} \mathrm{C}$. The operation was repeated after two days, to eliminate the progeny of germinated spores. Soil was transferred into $18 \mathrm{~cm}$ diameter clay pots. Three surface-sterilized pea seeds were sown per pot and inoculated with a suspension of $10^{8}$ bacterial cells per seed. Plants were incubated in a growth cabinet under the following program: $14 \mathrm{~h}$ light $/ 23^{\circ} \mathrm{C}, 10 \mathrm{~h}$ dark $/ 18^{\circ} \mathrm{C}$, with a $70 \%$ relative humidity. Roots were inspected for nodules after 30 days.

\section{Field studies: Most Probable Number (MPN) evaluation of rhizobia}

The estimation of indigenous background counts of rhizobia in the field was carried out by serially diluting soil and performing nodulation tests up to the extinction limits as described by Bergersen (1980) for $R$. leguminosarum bv. viciae, $R$. leguminosarum bv. trifolii, Sinorhizobium meliloti and Bradyrhizobium japonicum, using respectively Pisum sativum cv. Curico, Trifolium repens $\mathrm{cv}$. Dutch White, Medicago sativa cv. Roma, and Glycine max cv. Amelia as host legumes. Tests were carried out in $50 \mathrm{~mL}$ test tubes (or $200 \mathrm{~mL}$ Erlenmeyer flasks for peas) with agarized Fahraeus medium (Bergersen, 1980).

\section{Field releases}

The release took place on may 11th 1994 in Legnaro, $10 \mathrm{Km}$ south-east of Padua within the experimental field facilities of the Faculty of Agriculture. The soil was of clay type (41\% clay, $20 \%$ loam, 39\% sand) with $3.65 \%$ organic matter, and $\mathrm{pH} 7.9$ (Corich, 1995). The 
plots are located in open terrain, and the soil had been laid in place in 1989 by mixing sand, peat and clay components of allochthonous origin. No other crops had been cultivated in these units prior to the present experiment. The soil was weeded and tilled in preparation for the trial. Pea or faba bean plants were sown in a grid of 16 field plots in three replicates, receiving either one of the three GMMs, or the wild-type. Controls included three replicates of uninoculated peas, and one plot of uninoculated unsown soil. Each plot had an area of $1 \mathrm{~m}^{2}$, whose perimeter was framed by a $1-\mathrm{m}$ deep, $2-\mathrm{cm}$ thick concrete wall. Eighty pea seeds per plot were hand sown in ten rows at a depth of $4 \mathrm{~cm}$ in pre-drilled holes. Seeds in the same row were spaced $10 \mathrm{~cm}$ apart, rows were spaced $8 \mathrm{~cm}$ from each other, and border rows were at $10 \mathrm{~cm}$ from the plot's edge. Three replicate plots per treatment were set up. The bacterial inoculum consisted of $1 \mathrm{~mL}$ of cell suspension in saline solution containing amounts on the order of $10^{6}$ colony-forming units (CFUs), and was pipetted in the soil hole before placing each seed. Each block was kept covered with a wire mesh until plant emergence to protect seeds from rodents. The site was fenced, trespassing was warned against by appropriate signs, and the area was covered with a loose net to prevent birds from feeding and carrying over seeds and bacteria. In order to further ensure soil confinement of the GMMs and to test their lateral spreading potential, the site was planted with a surrounding double belt of pea host plants meant to act as trap crop to intercept and reveal possible horizontal escape of GMMs. Selected plots were watered with $4 \mathrm{~L} \cdot \mathrm{m}^{-2}$ of a $5 \%$ lactose solution, before bacterial release.

\section{Sampling GMMs from rhizosphere and from soil}

Rhizosphere-associated bacteria were isolated as follows: plants were carefully extracted and excess soil was roughly shaken off roots, further non-rhizospheric soil was eased off with a spatula, leaving only the most proximal layers of soil closely adhering to the surface. Roots were subsequently immersed in $50 \mathrm{~mL}$ of saline solution in Erlenmeyer flasks, which were shaken at 150 revolutions. $\mathrm{min}^{-1}$ for $2 \mathrm{~h}$. A final fast agitation was given by hand for $1 \mathrm{~min}$. Serial dilutions, the first of which was vortexed for one minute, were plated. Soil dry weight was measured after drying soil from the suspension in tin trays at $80^{\circ} \mathrm{C}$ for $72 \mathrm{~h}$ in a dry oven.

In order to isolate bacteria from bare soil, $1 \mathrm{~kg}$ was randomly collected by sequential random picks at a maximum depth of $15 \mathrm{~cm} .20 \mathrm{~g}$ of sieved, mixed soil were transferred to a beaker, and saline solution was added up to a volume of $200 \mathrm{~mL}$, and mixed for $1 \mathrm{~h}$ with a magnetic stirrer. Serial dilutions in physiological solution were carried out, and plated on media containing the appropriate selection. Soil was dried and weighed as above. When necessary for the detection of cells present in low amounts, less diluted suspensions were plated.

\section{Bacterial isolation from nodules}

Nodules were excised and surface-sterilized by a treatment including $5 \mathrm{sec}$ in $70 \%$ ethanol and $60 \mathrm{sec}$ in $1 \mathrm{mg} \cdot \mathrm{mL}^{-1} \mathrm{HgCl}_{2}$. Ten washes with sterile $\mathrm{H}_{2} \mathrm{O}$ were performed prior to transferring each nodule to a microtiter well containing $80 \mu \mathrm{L}$ of sterile saline solution. Each nodule was than squashed with forceps and dilutions of the resuspended content were plated on YM or TY plates.

\section{Randomly Amplified Polymorphic DNA (RAPD) analysis}

A loopful from a 3-day old bacterial colony was resuspended in $50 \mu \mathrm{L}$ lysis buffer $(0.25 \%$ sodium dodecyl sulphate, $0.05 \mathrm{M} \mathrm{NaOH}$ ) in an eppendorf tube and vortexed for $1 \mathrm{~min}$. The sample was heated at $95{ }^{\circ} \mathrm{C}$ for $15 \mathrm{~min}$ and centrifuged for $10 \mathrm{~min}$ to pellet debris. Ten $\mu \mathrm{L}$ from the supernatant were diluted into $90 \mu \mathrm{L} \mathrm{H}_{2} \mathrm{O}$. One $\mu \mathrm{L}$ of such dilution was added to $24 \mu \mathrm{L}$ of PCR mix (14.9 $\mu \mathrm{L}$ $\mathrm{H}_{2} \mathrm{O}, 2.5 \mu \mathrm{L} 10 \mathrm{X}$ amplification buffer (AB Analitica, Padova, Italy), $4 \mu \mathrm{L}$ of a nucleotide triphosphate mix (dATP, dCTP, dGTP, dTTP, each at $1.25 \mathrm{mM}$ ), $2.5 \mu \mathrm{L}$ of a $20 \mu \mathrm{M}$ primer solution, and 0.1 units of $T a q$ polymerase (AB Analitica, Padua, Italy)). The amplification program involved: $94{ }^{\circ} \mathrm{C}$ for $2 \mathrm{~min} 30 \mathrm{sec} ; 42^{\circ} \mathrm{C}$ for $1 \mathrm{~min} ; 65^{\circ} \mathrm{C}$ for $2 \mathrm{~min}\left(1 \mathrm{st}\right.$ cycle); $94{ }^{\circ} \mathrm{C}$ for $30 \mathrm{sec}, 42^{\circ} \mathrm{C}$ for $1 \mathrm{~min}$; $65^{\circ} \mathrm{C}$ for $2 \mathrm{~min}$ (2nd to 45 th cycle); followed by $72{ }^{\circ} \mathrm{C}$ for $5 \mathrm{~min}$. Amplified fragments were analyzed by electrophoresis in $1.2 \%$ agarose gel.

\section{Soil DNA extraction and GMM-specific PCR amplification}

Three plants per plot were randomly selected, avoiding the border rows. Rhizosphere soil was isolated as described above for the sampling of GMMs, and the soil suspension was pelleted at $22100 \times g$, weighed and resuspended in $\mathrm{H}_{2} \mathrm{O}$ to a concentration of $0.5 \mathrm{~g} . \mathrm{mL}^{-1}$. When bulk soil was tested, no prior treatment was done before resuspension. The extraction was performed on volumes containing $1 \mathrm{~g}$ of soil, with the method of Tas et al. (1995). Briefly, $1 \mathrm{~g}$ of soil was suspended in $2.5 \mathrm{~mL}$ of lysis buffer $\left(0.12 \mathrm{M} \mathrm{Na}_{2} \mathrm{HPO}_{4}\right.$ [pH 8.0], $1 \%$ [wt/vol] sodium dodecyl sulfate [SDS], $0.1 \mathrm{mg}$ of proteinase $\mathrm{K}$ per $\mathrm{mL}$ ) and incubated at $37{ }^{\circ} \mathrm{C}$ for $1 \mathrm{~h}$ with occasional shaking; $450 \mu \mathrm{L}$ of $5 \mathrm{M} \mathrm{NaCl}$ were then 
added to the samples and mixed thoroughly. Next, $375 \mu \mathrm{L}$ of $\mathrm{CTAB}-\mathrm{NaCl}$ solution ( $10 \%$ cetyltrimethylammonium bromide in $0.7 \mathrm{M} \mathrm{NaCl}$ ) were added to the mixture, which was carefully mixed again and incubated at $65{ }^{\circ} \mathrm{C}$ for $20 \mathrm{~min}$. The samples were then extracted with an equal volume of chloroform. A $0.5-\mathrm{mL}$ volume of Phase Lock Gel was added (5 Prime 3 Prime, Inc., Boulder, CO). The aqueous phase was transferred to a fresh test tube, and DNA was precipitated with 0.7 volume of isopropanol. The pellet was dried under vacuum, and dissolved in $200 \mu \mathrm{L}$ of sterile distilled water.

PCR amplification using two specific 20-mer primers, the first matching the synthetic promoter domain, the second within the lacZ gene, (GAAGCGATAATGCGGTCGAC, and GGTATAATATGCGCCATTAAGC) was carried out with a program based on the one described above for the RAPD technique, with the modification of the temperatures of annealing and elongation, set at $57{ }^{\circ} \mathrm{C}$ and $72{ }^{\circ} \mathrm{C}$, respectively. Amplified products were analyzed by electrophoresis in $1.2 \%$ agarose gel.

\section{Plasmid profiles}

The plasmid pattern of rhizobia was visualized according to Eckhardt (1978) with the modifications introduced by Espuny et al. (1987) consisting in a horizontal run with a longitudinal strip of SDS-containing gel behind the wells.

\section{Construction of strains Agri10 and 1114}

The strain chosen as background, which was the most frequent RAPD profile among pea-nodule occupants, was grown in TY broth, and cells were plated on TY agar supplemented with rifampicin in order to select spontaneous resistant mutants. This selection yielded strain Agri10. Strain 1114 was obtained by inserting plasmid pDG3, featuring a mercury and $l a c Z$ cassette under the control of a synthetic promoter, on a broad host range incQ vector (Giacomini et al., 1994) into the rifampicin resistant strain Agri 10. The plasmid was transferred from E. coli to $R$. leguminosarum by triparental conjugation as previously described (Corich et al., 1996). Briefly, overnight $10 \mathrm{~mL}$ liquid cultures of the donor, the recipient and the helper HB101 pRK2013 were centrifuged, resuspended in $50 \mu \mathrm{L}$ of saline solution and mixed on TY plates. After an overnight incubation at $30{ }^{\circ} \mathrm{C}$, the patch was resuspended, serially diluted in saline solution and plated on selective plates containing $10 \mu \mathrm{g} . \mathrm{mL}^{-1}$ mercury and $60 \mu \mathrm{g} \cdot \mathrm{mL}^{-1}$ rifampicin.

\section{Statistical analyses}

Counts of resident microbiota after GMM release were analyzed for impact effects by one-way chi-square test for equal proportions by using the SAS Stat Software version 6 (SAS Institute Inc. Cary, NC). As the variance of data (square of the standard deviation) was larger than their averages, an appropriate transformation was applied prior to the analysis, and upon testing different ones, the fourth root extraction gave the finest discriminatory resolution. The fourth root is also a recommended choice for the transformation of data sets spanning orders of magnitude, as was the case with the present ones. The unaveraged values from each different replicate were transformed and fed into the SAS FREQ procedure.

\section{ACKNOWLEDGEMENTS}

We are grateful to Toni Cantele and Giuliano Mosca for hosting the release within the experimental fields of the "Lucio Toniolo Agricultural Experimental Station" in Agripolis, Legnaro. We thank John Beringer for strain Nb1. The statisticians Annie Deslauriers and Sergio Rossi are gratefully acknowledged for advice in the choice of the SAS procedure used for the analyses of data and for critically evaluating its result. We thank two anonymous referees for the helpful criticism that led to a substantial improvement of the manuscript. This work was made possible by the European Union IMPACT I and IMPACT II Grants.

Received July 5, 2006; accepted March 5, 2007.

\section{REFERENCES}

Basaglia M, Casella S, Nuti MP, Peruch U, Poggiolini S, Vian P, Vanderleyden J, De Troch P, Vamerali T, Mosca G (2003) Field release of genetically marked Azospirillum brasilense in association with Sorghum bicolor L. Plant Soil 256: $281-290$

Bergersen FJ (1980) Methods for evaluating biological nitrogen fixation. John Wiley \& Sons, Chichester, New York, Brisbane, Toronto

Beringer JE (1974) R-factor transfer in Rhizobium leguminosarum. J. Gen. Microbiol. 84: 188-198

Corich V (1995) Immissione nell'ambiente di Rhizobium leguminosarum bv, viciae geneticamente modificati. Ph.D. thesis. University of Padova

Corich V, Giacomini A, Concheri G, Ritzerfeld B, Vendramin E, Struffi P, Basaglia M, Squartini A, Casella S, Nuti MP, Peruch U, Poggiolini S, De Troch P, Vanderleyden J, Fedi S, Fenton A, Moenne-Loccoz Y, Dowling DN, O'Gara F (1995) Environmental impact of genetically modified Azospirillum brasilense, Pseudomonas fluorescens and Rhizobium leguminosarum released as soil/seed inoculants. In Jones D, ed, Biosafety results of field tests with genetically modified plants and microorganisms, Monterey Ca., USA, November 19-23 1995 
Corich V, Bosco F, Giacomini A, Basaglia M, Squartini A, Nuti MP (1996) Fate of genetically modified Rhizobium leguminosarum biovar viciae during long-term storage of commercial inoculants. J. Appl. Bacteriol. 81: 319-328

Corich V, Giacomini A, Basaglia M, Vendramin E, Vian P, Carlot M, Squartini A, Casella S, Nuti MP (2000) The field release and monitoring of rhizobial strains marked with $l a c Z$ and mercury resistance genes. In Jansson J, Van Elsas JD, Bailey M, eds, Tracking genetically engineered microorganisms, Landes Biosciences, Georgetown, TX, USA

Corich V, Giacomini A, Basaglia M, Vendramin E, Vian P, Carlot M, Squartini A, Casella S, Nuti MP (2001a) Aspects of marker/reporter stability and selectivity in soil microbiology Microb. Ecol. 41: 333-340

Corich V, Giacomini A, Carlot M, Simon R, Tichy H-V, Squartini A, Nuti MP (2001b) Comparative strain-typing of Rhizobium leguminosarum bv. viciae natural populations. Can. J. Microbiol. 47: 580-584

Cullen DW, Nicholson PS, Mendum TA, Hirsch PR (1998) Monitoring genetically-modified rhizobia in field soils using the polymerase chain reaction. J. Appl. Microbiol. 84: $1025-1034$

Da HN, Deng SP (2002) Surviving and persistence of genetically modified Sinorhizobium meliloti strain 104 A14 in soil. Appl. Soil Ecol. 22: 1-14

Eckhardt T (1978) A rapid method for the identification of plasmid deoxyribonucleic acid in bacteria. Plasmid 1: 584-588

Espuny MR, Ollero FJ, Bellogin RA, Ruiz-Sainz JE, Perez Silva J (1987) Transfer of the Rhizobium leguminosarum biovar trifolii symbiotic plasmid pRtr5a to a strain of Rhizobium sp. that nodulates on Hedysarum coronarium. $J$. Appl. Bacteriol. 63: 13-20.

Figurski DH, Helinski DR (1979) Replication of an origincontaining derivative of plasmid RK2 dependent on a plasmid function provided in trans. Proc. Nat. Acad. Sci. USA 76: $1648-1652$

Giacomini A, Ollero FJ, Squartini A, Nuti MP (1994) Construction of multipurpose gene cartridges based on a novel synthetic promoter for high-level gene expression in Gram-negative bacteria. Gene 144: 17-24

Hagen M, Pühler A, Selbitschka W (1997) The persistence of bioluminescent Rhizobium meliloti strains L1 (RecA-) and L33 (RecA+) in non-sterile microcosms depends on the soil type, on the co-cultivation of the host legume alfalfa and on the presence of an indigenous $R$. meliloti population. Plant Soil 188: 257-266

Hirsch PR (1996) Population dynamics of indigenous and genetically modified rhizobia in the field. New Phytol. 133: 159-171

Hirsch PR (2004) Release of transgenic bacterial inoculants rhizobia as a case study. Plant Soil 266: 1-10

Miethling R, Tebbe C (2004) Resilience of a soil-established, genetically modified Sinorhizobium meliloti inoculant to soil management practices. Appl. Soil Ecol. 25: 161-167

Naseby DC, Lynch JM (1998) Impact of wild type and genetically modified Pseudomonas fluorescens on soil enzyme ac- tivities and microbial population structure in the rhizosphere of pea. Mol. Ecol. 7: 617-625

Nuti MP, Squartini A, Giacomini A (1994) European Community regulation for the use and release of genetically modified organisms (GMOs) in the environment. In O'Gara F, Dowling D, Boesten B, eds, Molecular Ecology of Rhizosphere Microorganisms, VCH Publ., Weinheim, Germany

Nuti MP, Basaglia M, Bonfante P, Casella S, Corich V, Dal Maistro L, Giacomini A, Martini I, Peruch U, Poggiolini S, Squartini A, Vian P (1997) Field release of genetically modified biofertilizers and phytostimulators. In Matsui S, Miyazaki S, Kasamo K, eds, Proceedings of the 4th International Symposium on the Biosafety Results of Field Tests of Genetically Modified Plants and Microorganisms, published by the Japan International Research Center for Agricultural Sciences (JIRCAS), pp 101-111

Nuti MP, Russo A, Toffanin A, Casella S, Corich V, Squartini A, Giacomini A, Peruch U, Basaglia M (2003) What did we learn from 24 field releases of GMMs in Italy? In Lelley T, Balasz E, Tepfer M, eds, Ecological Impact of GMO Dissemination in Agro-Ecosystems, Facultas Verlags, Wien, p 45-54

Paffetti D, Daguin F, Fancelli S, Gnocchi S, Lippi F, Scotti C, Bazzicalupo M (1998) Influence of plant genotype on the selection of nodulating Sinorhizobium meliloti by Medicago sativa. Antonie van Leeuwenhoek 73: 3-8

Pitkajarvi J, Rasanen LA, Langenskiod J, Wallenius K, Niemi M, Lindstrom K (2003) Persistence, population dynamics and competitiveness for nodulation of marker genetagged Rhizobium galegae strains in field lysimeters in the boreal climatic zone. FEMS Microbiol. Ecol. 46: 91-104

Resca R, Basaglia M, Poggiolini S, Vian P, Bardin S, Walsh UF, Enriquez Barreiros CM, O'Gara F, Nuti MP, Casella S, Peruch U (2001) An integrated approach for the evaluation of biological control of the complex Polymixa betae/Beet Necrotic Yellow Vein Virus, by means of seed inoculants. Plant Soil 232: 215-226

Schwieger F, Tebbe CC (2000) Effect of field inoculation with Sinorhizobium meliloti L33 on the composition of bacterial communities in rhizospheres of a target plant (Medicago sativa) and a non-target plant (Chenopodium album)-linking of 16S rRNA gene-based single-strand conformation polymorphism community profiles to the diversity of cultivated bacteria. Appl. Environ. Microbiol. 66: 3556-3565

Tas E, Saano A, Leinonen P, Lindström K (1995) Identification of Rhizobium in peat-based inoculants by DNA hybridization and PCR-application in inoculant quality control. Appl. Environ. Microbiol. 61: 1822-1827

Tichy H, Simon R (1994) Genetic typing of microorganisms: Current concepts and future prospects. In O'Gara F, Dowling D, Boesten B, eds, Molecular Ecology of Rhizosphere Microorganisms, VCH Publ., Weinheim, Germany

Tobar RM, Azcón-Aguilar C, Sanjuan J, Barea JM (1996) Impact of a genetically modified Rhizobium strain with 
improved nodulation competitiveness on the early stages of arbuscular mycorrhiza formation. Appl. Soil Ecol. 4: 15-21

van Dillewijn P, Soto MJ, Villadas PJ, Toro N (2001)

Construction and environmental release of a Sinorhizobium meliloti strain more competitive for alfalfa nodulation. Appl.

Environ. Microbiol. 67: 3860-3865 van Veen JA, van Overbeek LS, van Elsas JD (1997) Fate and activity of microorganisms introduced into soil. Microbiol. Mol. Biol. Rev. 61: 121-135

Vincent JM (1970) A manual for the practical study of the rootnodule bacteria. IBP Handbook no. 15, Blackwell Scientific Publications, Oxford 